\title{
CAMINHOS DA UNIVERSIDADE RUMO AO SÉCULO XXI: PONTOS E ESTRATÉGIAS PARA A SUA ORIENTAÇÃO NA VISÃO DE EDUCADORES BRASILEIROS ${ }^{1}$
}

\author{
Paulo Gomes Lima ${ }^{2}$ \\ Franciana Castro \\ Maria Aparecida Vivan de Carvalho
}

\begin{abstract}
RESUMO: A principal preocupação desse estudo é, através das reflexões nele contidas, apontar caminhos que poderão contribuir para que as nossas universidades, face à inevitável globalização, possam se instrumentalizar de forma coesa, de modo a cumprir sua missão na formação e transformação do homem. Para tal, organizamos esse trabalho sobre a universidade partindo de sua gênese, passando pelo momento atual e chegando até as perspectivas que se tem da universidade pretendida para o próximo milênio; para isso foram coletados dados que permitiram analisar alguns de seus problemas e, através dessa análise levantar possíveis soluções frente ao emergente século XXI.
\end{abstract}

Palavras chaves: Universidade - Mudança - Século XXI - Propostas

\section{THE UNIVERSITY TO THE XXI CENTURY:}

The perspectives of Brazilian Educators

\begin{abstract}
The main concern of this study is, through the reflection, to be able to point to possible contributions to our universities that are facing the inevitable globalization; it is assumed that it is important to have good instruments to actively participate in the formation and transformation of men and women. To accomplish this, the paper deals with the theme analyzing the genesis of the University, drawing the picture of the present moment and giving the desired perspectives for the next millennium; data were collected to base the analysis of these problems and the solutions proposed, taking into account the emergent XXI Century.
\end{abstract}

Key words: University - Changes - Century XXI - Proposals

\section{Com o Olhar Voltado para a Universidade}

Atualmente, a universidade apresenta inúmeras dificuldades em acompanhar muitas das mudanças que vêm ocorrendo no mundo. Nesse sentido, muito tem sido publicado sobre a universidade, na maioria das vezes, no intuito de conhecê-la um pouco melhor, de diagnosticar seus problemas e propor alternativas de solução, de conduzir o leitor a reflexões aprofundadas para promoção de ações efetivas na prática das atividades fins da universidade (ensino, pesquisa, extensão).

\footnotetext{
' Artigo recebido para publicação em agosto de 2000; aceito em dezembro de 2000

' Endereço para correspondência: Rua dos Expedicionários, 1090, Artur Nogueira, Centro - São Paulo-SP - Cep 13160-000 - e-mail paulogl.lima@bol:com.br
}

8
São de extrema relevância estas tentativas de conhecer e entender a universidade, e procura-se, em parceria com alguns autores e professores, trazer através deste trabalho, contribuições para a visão da universidade para o próximo milênio.

Numa ação conjunta resgatamos as informações sobre o tema em foco e elaboramos um arranjo na forma de 5 (cinco) partes, que se caracterizam por serem momentos que propiciam um amplo panorama, um olhar especial para as questões da universidade.

No primeiro momento, trazemos de forma sucinta a história da universidade, seguida de uma contextualização sobre a universidade hoje. Posteriormente avançamos numa evidente intenção crítica de expor a problemática central, a universidade do

Paidéia, FFCLRP-USP, Rib. Preto, jan/julho/2000. 
século XXI, entrelaçando as análises de diversos autores.

Buscando delinear um pouco mais a visão atual sobre a universidade do próximo século, elegemos 10 (dez) professores das universidades estaduais, respectivamente, de Londrina (UEL/ Brasil) e de Campinas (UNICAMP/Brasil), para relatar suas percepções, revelar seus posicionamentos, enriquecendo com elementos significativos nossa pesquisa.

Num último momento procuramos caminhar no sentido de nos posicionarmos sobre 0 assunto, afivelando pontos essenciais no processo de reflexão.

\section{Gênese e Desenvolvimento da Universidade}

Em todas as épocas, em todas as sociedades, a humanidade tem se preocupado com a organização social, política, econômica e cultural de seus povos, ora legitimando a estruturação das classes sociais hegemônicas, ora lutando pela superação dessas e/ou buscando a sua transformação social. Nessa ótica, o veículo da estruturação social das dispares sociedades em diferentes períodos históricos foi sem dúvida (e ainda continua a sê-lo em nossa contemporaneidade) o conhecimento.

Conhecimento aqui entendido não somente como acumulação linear ou circular de saberes emergentes, entretanto, também e principalmente, como processo de assunção de saberes que se constroem, e se construindo flexibilizam-se às modificações que se fizerem necessárias em consonância com o momento histórico circunstancial ou mesmo ao momento histórico desejado, sempre aberto a novas considerações e postulados que contribuam para 0 seu dinâmico desenvolvimento.

Depreende-se daí que no afã de garantir que o conhecimento e seu processo se legitimassem e alcançassem níveis consideráveis de desenvolvimento é que a sociedade humana criou a universidade e muitas conceituações a seu respeito. Cunha (1988), por exemplo, diz entender a universidade tal como Gramsci, um aparelho de hegemonia, cuja especificidade centra-se na formação de intelectuais tradicionais e intelectuais orgânicos da burguesia, existindo dentro de seu seio lutas hegemônicas que explicitam o porquê das suas crises de identidade. Wanderley (1991, p.11), por sua vez, assevera que a

Paidéia, FFCLRP-USP, Rib. Preto, jan/julho/2000. universidade é lugar privilegiado que oferece oportunidades muito mais abrangentes do que simplesmente proporcionar conhecimento científico ou de uma cultura universal, criar ou preconizar saberes, ou seja, assinala que esta deve "buscar uma identidade própria e uma adequação à realidade nacional" de um povo. Teixeira (1998, p.41), sobre a definição de universidade argumenta que:

"Fundamentalmente, a universidade é a reunião de adultos já avançados na experiência intelectual e profissional com jovens à busca de sua formação e seu preparo para atividades dentro e fora dela e, ao mesmo tempo, a instituição devotada à guarda e ao cuidado da cultura humana, que lhe cabe zelar e lavrar como seu campo especial de trabalho..."

Embora essas conceituações tenham o seu lugar e sejam igualmente relevantes, para compreendermos melhor a universidade, seu ideal e natureza teleológica, necessário se faz irmos mais além; convém investigarmos a sua gênese e o seu processo de desenvolvimento no desenrolar da história da humanidade.

\section{As Primeiras Universidades}

Apesar de muitos autores serem unânimes em afirmar que o nascimento da universidade se deu no período medieval (entre os séculos XI e XIII), Freitas $(1985$, p.7), a partir de S6crates, concebe a universidade como "o lugar onde o homem está à procura de si", buscando dar à sua vida consciência e felicidade; dessa maneira, declara Sócrates como o fundador da primeira universidade de que se tem notícia. Nesta mesma perspectiva, Pereira (1990) atribui a Aristóteles, o fundador do Liceu, tal título.

Se continuássemos a discorrer sobre a gênese da universidade por essa perspectiva, teríamos, com certeza, que fazer uma digressão, por exemplo, até a história do povo israelita com sua "escola dos profetas" (bem anterior aos filósofos citados), cujo objetivo primordial era a preservação da cultura nacional e principalmente na formação teocêntrica dos sacerdotes que seriam os dirigentes da nação; e, antes destes os fenícios, os prováveis inventores da escrita como atesta a arqueologia e ainda, por que não mencionarmos um expoente grego de grande impor- 
tância como Platão, o fundador da Academia e contemporâneo de Aristóteles?

Da mesma sorte Castro $(1985$, p. 16$)$ recorrendo a Paul Monroe afirma que a gênese da universidade deu-se tanto na Grécia (através da Universidade de Atenas [resultante da combinação de três escolas: Academia, Escola Peripatética e a Estóica] e a Universidade de Alexandria [tida como Centro Intelectual do Mundo]), quanto em Roma (através da Universidade de Roma, cuja origem se deu com a biblioteca fundada por Vespasiano [69 - 79 d.C.] no Templo da Paz, construído após o incêndio de Nero). Para aclarar esta afirmação, Castro (1985) ressalva que o emprego da palavra universidade no mundo clássico não teria a mesma origem do termo utilizado na idade média, e recorre então a Ruy Afonso da Costa Nunes (1979, p.212) que esclarece:

"Entre os romanos o termo universitas designara um colégio, uma associação. Na idade Média aplicou-se a um conjunto de pessoas, usou-se como fórmula de tratamento no inicio das cartas universitas vestra, 'a todos nós', que soava com a nossa fórmula 'prezados senhores' e também serviu para designar uma pessoa jurídica tal como universitas mercatorum, a corporação de comerciantes..."

Luckesi (1991, p.35), por outro lado, aponta que o nascimento propriamente dito da Universidade se deu entre o final da idade média e a reforma (entre os séculos XI e XV), pois, segundo observa, foi justamente neste período em que a Igreja Católica, "no sentido de legitimar a sua ação política $e$ religiosa, responsabiliza-se pela unificação do ensino superior em um só órgão, a universidade".

Lauand $(1987$, p.94), diligentemente concorda que a gênese da universidade tenha se dado na idade média, entretanto, alude o surgimento e a manutenção da universidade "como herdeira direta da Academia de Platão", explicitando que:

'E certo que o termo 'Universidade', por ocasião do surgimento das universidades, tem inicialmente um significado sociológico (grêmio, corporação de mestres e estudantes) e depois, muito cedo, também o significado de universitas litterarum. 'Universidade' liga-se a 'um termo fundamental da linguagem humana: universum' que, por sua vez, indica a profunda unidade da totalidade do real. E é isto, em que pesem todas as naturais e profundas diferenças, que unem a Universidade de hoje à medieval è à Academia de Platão."

Ullmann e Bohnen (1994, p.57-8) resolvem a questão observando que convencionalmente se concebe a gênese da universidade "tomando-se como parâmetro a universitas medieval, com o seu cosmopolitismo, com o seu significado social e politico, com a sua organização jurídico-estatuária, a sua homologação oficial pelos papas elou reis e, ain$d a$, a concessão da licentia ubique docendi", sendo desta forma, pode-se, segundo os autores, afirmar que não "existiram universidades antes do século XII ou XIII". Entretanto, os autores não descartam a possibilidade das universidades medievais terem se "inspirado em modelos anteriores"; como, por exemplo, a "escola ascético-terapêutica de Buda", a "escola de Confúcio", a "escola de Pitágoras", a "Academia de Platão", o "Liceu de Aristóteles" e a "escola dos Sofistas", que preferiram denominar de pré-universidades, pois quando reuniam algum requisito do padrão medieval, outros estavam ausentes, distanciando-se do referencial "ótimo" do medievo; além de algumas instituições com traços de universidade (como veremos no Quadro 1), intermediárias às primeiras universidades propriamente ditas e que também influenciaram o seu surgimento.

Como características das universidades medievais, Wanderley (1991, p.16) destaca "seu caráter conservador, suas polêmicas teológicas e de outros teores, como as disputas entre nominalistas e realistas, as aulas orais, o regime de internato, o espírito universalista do professorado italiano", entre outras. Cabe ressaltar que o fim último do saber nessas universidades, era o próprio saber, portanto, um "saber desinteressado".

Da Idade Média, a universidade percorre a renascença, a reforma e a contra-reforma (Séc.XVI), período denominado de Idade Moderna, todavia, não acompanhando o espírito que a época apregoava (Luckesi, 1991, p.31-32); neste período histórico a universidade traz

Sobre os seus quadros, certa imposição de uma 
atitude defensiva, de guarda das verdades já constituídas, definidas e definitivas, estáticas e restritivas, no sentido de não acrescentar os valores do passado às numerosas descobertas que se faziam. Nessa fase a universidade se caracteriza pelas repetições dogmáticas, ditadas, como verdades incontestáveis, de cátedras..." (Ibidem)

Quadro 1: Gênese e Expansão da Universidade

\begin{tabular}{|c|c|c|c|}
\hline PRÉ -UNIVERSIDADES & $\begin{array}{c}\text { INSTITUIÇÔES COM } \\
\text { TRAÇOS DE UNIVERSIDADE }\end{array}$ & \multicolumn{2}{|c|}{$\begin{array}{l}\text { PRIMEIRAS UNIVERSIDADES } \\
\text { PROPRIAMENTE DITAS }\end{array}$} \\
\hline $\begin{array}{l}\text { - Escola ascéptico-terapêutica de Buda } \\
\text { (ca. 650-550 a.C.) - sem cunho } \\
\text { ontológico, libertação da dor. }\end{array}$ & \multirow{12}{*}{$\begin{array}{l}\text { O Mouseion (323-285 a.C.), } \\
\text { instituição voltada, no começo, apenas } \\
\text { para a investigação, somente no } \\
\text { decorrer do tempo que o ensino foi } \\
\text { incorporado. } \\
\text { - A Didascália (II e III séc. d.C.) - } \\
\text { escola catequética, reunindo filosofia e } \\
\text { cristianismo em defesa do evangelho. }\end{array}$} & \multirow{12}{*}{$\begin{array}{l}\text { Bolonha } \\
\text { Paris } \\
\text { Pádua } \\
\text { Nápoles } \\
\text { Salamanca } \\
\text { Oxford } \\
\text { Cambridge } \\
\text { Coimbra } \\
\text { Praga } \\
\text { Viena } \\
\text { Heidelberg } \\
\text { Leipzig } \\
\text { Lovaina. } \\
\text { Barcelona } \\
\text { Basiléia } \\
\text { Tübingen } \\
\text { Upsala } \\
\text { Lima } \\
\text { México } \\
\text { Leiden } \\
\text { Edimburgo } \\
\text { Córdoba } \\
\text { Harvard } \\
\text { Yale } \\
\text { Gottingen } \\
\text { Princeton } \\
\text { Moscou } \\
\text { São Petersburgo } \\
\text { Berlim } \\
\text { Londres }\end{array}$} & \multirow{12}{*}{$\begin{array}{l}(1108) \\
(1211) \\
(1222) \\
(1224) \\
(1243) \\
(1249) \\
(1284) \\
(1290) \\
(1348) \\
(1365) \\
(1386) \\
(1409) \\
(1425) \\
(1450) \\
(1460) \\
(1477) \\
(1477) \\
(1551) \\
(1553) \\
(1575) \\
(1583) \\
(1613) \\
(1636) \\
(1701) \\
(1737) \\
(1746) \\
(1755) \\
(1789) \\
(1810) \\
(1836)\end{array}$} \\
\hline & & & \\
\hline $\begin{array}{l}\text { Escola de Pitágoras (ca. } 582-500 \\
\text { a.C.) - caracterizada por uma } \\
\text { comunidade esotérica de vida comum e } \\
\text { celibatária. }\end{array}$ & & & \\
\hline & & & \\
\hline $\begin{array}{l}\text { - Escola de Confúcio (511-478 a.C.) - } \\
\text { escola ético-religiosa. }\end{array}$ & & & \\
\hline & & & \\
\hline $\begin{array}{l}\text { A Academia de Platão (429-347 } \\
\text { a.C.) - idéia suprema do Bem, } \\
\text { compromisso com a Episteme }\end{array}$ & & & \\
\hline & & & \\
\hline \multirow[t]{3}{*}{$\begin{array}{l}\text { - O Liceu de Aristóteles (384-322 } \\
\text { a.C.) - busca da verdade/escola } \\
\text { peripatética. }\end{array}$} & & & \\
\hline & & & \\
\hline & & & \\
\hline $\begin{array}{l}\text { - Os Sofistas, o Jardim de Epicuro e o } \\
\text { Pórtico de Zenon (ca. } 341-263 \text { a.C.) - } \\
\text { Estudos isolados, falta de objetivo com } \\
\text { a coletividade. }\end{array}$ & & & \\
\hline
\end{tabular}

\section{Teleologia da Universidade}

A idéia de universidade para Napoleão centrava-se na finalidade sócio-política, na conservação da ordem social e formação de mentalidades, através de uma doutrina comum, cujo objetivo era manter a hegemonia situacional, firmemente patamarizada na coerção; eliminando opositores e a formação de intelectuais orgânicos para o seu Régime.

A Universidade Real de Halle, primando por não perder sua identidade cultural e nacional, temerosa da invasão napoleônica, muda-se para Berlim em 1810, tendo Humboldt como seu fundador. Cunha (1988) traz que, mais do que uma mudança física, a universidade de Berlim mudou a sua

Paidéia, FFCLRP-USP, Rib. Preto, jan/julho/2000. "concepção de universidade", marcada por um lado do caráter liberal (representado por Humboldt e Schleiermacher) e por outro lado do caráter autoritário (Fitche).

Sobre o fundamento liberal da universidade, Karl Jaspers apud Ricoeur (1983, p.11), apregoa que a teleologia de toda universidade deve ser " $a$ procura da verdade na comunidade de pesquisadores e estudantes", sem constrangimento, isto somente será patente através da "idéia de universidade" pautada pela "liberdade acadêmica, definida positivamente pela responsabilidade a respeito do saber" (Ibidem, p.14-15) e esta responsabilidade deve abranger também autonomia financeira, liberdade para discentes e docentes, enfim, a possibilidade da constru- 
ção do "saber", "sem constrangimento".

Para o Cardeal Newman, a universidade deveria ser um lugar de ensino universal e liberal, e exatamente por isso que o seu fim último deveria se prender mais à "formação intelectual do que a formação profissional", (Dreze e Debelle,
1983, p.37).

Dreze e Debelle (1983), de maneira mais expansiva propõem-nos um quadro sin6ptico sobre a "universidade do espírito" e a "universidade do poder", que com certeza, contribuirá para uma visão geral do que expomos até aqui, conforme Quadro 2.

Quadro 2: Visão Sinóptica das Cinco Concepções de Universidade

\begin{tabular}{|c|c|c|c|c|c|}
\hline \multicolumn{3}{|c|}{ A UNIVERSIDADE DO ESPÍRITO } & \multicolumn{3}{|c|}{ A UNIVERSIDADE DO PODER } \\
\hline Autor principal & $\begin{array}{l}\text { J. H. Newman } \\
\text { (um centro de } \\
\text { educação) }\end{array}$ & \begin{tabular}{l}
\multicolumn{1}{c|}{ K. Jaspers } \\
(uma \\
comunidade de \\
pesquisadores)
\end{tabular} & $\begin{array}{l}\text { A. N.Whitehead } \\
\text { (um núcleo de } \\
\text { progresso) }\end{array}$ & $\begin{array}{c}\text { Napoleão } \\
\text { (um modelo } \\
\text { intelectual) }\end{array}$ & $\begin{array}{l}\text { URSS } \\
\text { (um fator de } \\
\text { produção) }\end{array}$ \\
\hline Finalidade & $\begin{array}{l}\text { Aspiração do } \\
\text { Indivíduo ao } \\
\text { Saber }\end{array}$ & $\begin{array}{c}\text { Aspiração da } \\
\text { humanidade à } \\
\text { verdade }\end{array}$ & $\begin{array}{l}\text { Aspiração da } \\
\text { sociedade ao } \\
\text { progresso }\end{array}$ & $\begin{array}{l}\text { Estabilidade } \\
\text { política do } \\
\text { Estado }\end{array}$ & $\begin{array}{l}\text { Edificação da } \\
\text { Sociedade } \\
\text { Comunista }\end{array}$ \\
\hline $\begin{array}{l}\text { Concepção } \\
\text { Geral }\end{array}$ & $\begin{array}{l}\text { Uma educação } \\
\text { geral e liberal por } \\
\text { intermédio do } \\
\text { saber universal }\end{array}$ & $\begin{array}{c}\text { A unidade da } \\
\text { pesquisa e do } \\
\text { ensino no centro } \\
\text { do universo das } \\
\text { ciências }\end{array}$ & $\begin{array}{c}\text { A simbiose da } \\
\text { pesquisa e do } \\
\text { ensino a serviço } \\
\text { da imaginação } \\
\text { criadora }\end{array}$ & $\begin{array}{l}\text { Um ensino } \\
\text { profissional } \\
\text { uniforme, } \\
\text { confiado a um } \\
\text { grupo } \\
\text { profissional } \\
\end{array}$ & $\begin{array}{l}\text { Um instrumento } \\
\text { Funcional de } \\
\text { Formação } \\
\text { Profissional e } \\
\text { Política }\end{array}$ \\
\hline $\begin{array}{l}\text { Princípios de } \\
\text { Organização }\end{array}$ & $\begin{array}{c}\text { Uma pedagogia } \\
\text { do } \\
\text { desenvolvimento } \\
\text { intelectual } \\
\text { (Internato e } \\
\text { tutors) }\end{array}$ & $\begin{array}{c}\text { Uma sã } \\
\text { organização da } \\
\text { faculdade - A } \\
\text { liberdade } \\
\text { acadêmica }\end{array}$ & $\begin{array}{c}\text { Um corpo } \\
\text { docente criador } \\
\text { estudantes } \\
\text { capazes de } \\
\text { aplicar alguns } \\
\text { princípios gerais }\end{array}$ & $\begin{array}{l}\text { Uma hierarquia } \\
\text { administrativa - } \\
\text { Programas } \\
\text { Uniformes }\end{array}$ & $\begin{array}{l}\text { Uma manipulação } \\
\text { controlada da } \\
\text { oferta de } \\
\text { diplomados - } \\
\text { Apelo a todas as } \\
\text { forças produtivas } \\
\text { da nação }\end{array}$ \\
\hline $\begin{array}{l}\text { Conclusão } \\
\text { Quanto ao } \\
\text { problema da } \\
\text { massa }\end{array}$ & $\begin{array}{r}\text { Uma re } \\
\text { ensi } \\
\text { universi }\end{array}$ & $\begin{array}{l}\text { de diversificada de } \\
\text { no superior no seic } \\
\text { dades conservam s }\end{array}$ & $\begin{array}{l}\text { instituições de } \\
\text { o da qual as } \\
\text { ua originalidade }\end{array}$ & $\begin{array}{c}\text { Uma rede } \\
\text { oficial } \\
\text { Uniforme para a } \\
\text { massa e a elite }\end{array}$ & $\begin{array}{c}\text { Adaptação do } \\
\text { número às } \\
\text { necessidades da } \\
\text { economia e } \\
\text { diversificação das } \\
\text { instituições }\end{array}$ \\
\hline
\end{tabular}

FONTE: Dreze, J. \& Debelle, J. Concepções da Universidade.. Fortaleza: UFC, 1983, p.29

A idéia de universidade para Whitehead e, por conseguinte, a sua finalidade, centra-se na "aspiração da sociedade ao progresso" e enfatiza que "as universidades säo os principais agentes desta fusão de atividades progressivas num instrumento capaz de progresso" (Ibidem, p.64), e que nas universidades isto será conseguido mediante o estímulo da criatividade através da pesquisa científica que deverá estar sempre em processo de simbiose com o ensino.
$\mathrm{Na}$ antiga URSS, a idéia de universidade convergia para a "edificação da sociedade comunista", cuja finalidade deveria ser a de "difundir os conhecimentos científicos e políticos entre a população, a começar pelos estudantes" (Ibidem, p.106), onde toda a doutrinação sobre o comunismo deveria ser trabalhada.

E hoje, prestes a adentrarmos o século XXI qual a missão da universidade? Que perspectivas de Paidéia, FFCLRP-USP, Rib. Preto, jan/julho/2000. 
universidade existem para o próximo milênio? Quais caminhos a universidade deveria trilhar para firmarse como uma unidade na diversidade? A seguir, mediante essas indagações, procuraremos encontrar em diversos autores algumas pistas que nos ajudarão nesse esforço, bem como alinhavando considerações que possam contribuir para se repensar a universidade pretendida.

Sucre e González (1994) enumeram seis funções específicas que a universidade deve lutar por alcançar:

1) treinar estudantes, docentes e pesquisadores, uns com mais experiência do que outros, para resolver problemas;

2) ensinar a delinear problemas pertinentes, acerca da realidade que nos rodeia, especialmente no enfoque das disciplinas com que se trabalha;

3) formar e informar sobre os conhecimentos já estabelecidos pelos que trabalham as disciplinas universitárias;

4) integrar o conhecimento parcial de cada disciplina num contexto mais geral que permita relacioná-la a outros conhecimentos;

5) manter o corpo docente atualizado para que se alcance os quatro pontos anteriores;

6) relacionar-se com a coletividade, através de trabalhos técnicos e científicos, com atenção para os problemas de importância ou urgência para a sociedade, que requeiram conhecimento especializado.

Frente aos novos desafios postos à Universidade pela sociedade, quanto ao avanço tecnológico, surgem novas linguagens e termos como desemprego, ecologia, paz, formação de um cidadão pleno e outras questões e também muitos problemas aí se estabelecem; dentre eles podemos mencionar a falta de recursos financeiros, o aumento da demanda social com diversificação da clientela, o aumento do desemprego, alterações na economia, e dada a complexidade das mudanças a que estamos sendo submetidos, que afetam não só as instituições de ensino, mas todos que a pensam e a executam com o objetivo de realizar um trabalho que proporcione o bem estar social. Neste sentido, Fávero (1997, p.13), menciona que para

"analisar as funções da Universidade na sociedade é necessário determinar não só os objetivos pedagógicos, mas também os objetivos sociais, políticos e culturais. É fundamental definir o grau de participação de cada uma das instâncias que constitui a organização universitária, bem como o grau de autonomia que se pretende atingir".

Nesse sentido, entendemos a importância da articulação entre os objetivos, mas quanto a definição do grau de participação e autonomia universitária, há de se ressaltar que não deve ser estabelecido num ponto ou pontos, pois podemos correr o risco de termos uma visão simples e reducionista da função que a Universidade deve exercer na sociedade.

Belloni (1992, p.73) enfatiza que a "função da Universidade é apenas uma: gerar saber, $e$ este deverá estar comprometido com a verdade, a justiça, a beleza e a igualdade", convivendo entre conflitos e contradições da sociedade, proporcionando o envolvimento num caráter universal e plural. A mesma autora acrescenta que:

"A Universidade tem a seu cargo a função de gerar saber comprometido com a ruptura e a inovação e neste sentido, sua característica dominante é a busca do conhecimento, do inédito; por conseqüência a criação de algumas das condições para a transformação, cuja ocorrência depende de condições estruturais da sociedade como um todo".( p.74)

Segundo Morais (1992), para que compreendamos as Universidades, necessitamos entender como se dá o modo de relacionamento de cada instituição universitária com sua realidade social mais próxima e quais os seus modos de inserção na ordem internacional do conhecimento. Entendendo assim, que há um controle do conhecimento, onde se estabelece uma diferença entre os países e, conseqüentemente, na Universidade; podemos dizer então, que no Brasil há uma diferença interna: existem as universidades centrais (minoria), caracterizadas por serem produtoras de conhecimento/saber, com bibliotecas e laboratórios bem estruturados, com recursos para a pesquisa, seus professores são reconhecidos; por outro lado temos as universidades periféricas (maioria), distribuidoras de conhecimento, dependentes, reprodutoras, que produzem pouco, com escas- 
sos recursos para pesquisa, professores pouco privilegiados, portanto, representando um quadro estarrecedor para a realidade da Universitária brasileira.

Diante do exposto, enfatizamos a importância de uma Universidade crítica, que compreenda seus limites e possibilidades, e seja capaz de romper com as desigualdades internas que refletem o poder econômico e político primando, dentro de seu contexto nacional e global, pela emancipação do homem como sujeito de sua própria história.

Lampert (1997) a este respeito argumenta que a Universidade ainda não consegue democratizar o ensino; amenizar as graves questões sociais; resgatar as dimensões epistemológicas, pedagógicas e transformadoras de suas atividades de ensino havendo, portanto, necessidade de se repensar e encaminhar estes pontos na melhor perspectiva coletiva do compromisso que entende a profundidade e importância da Universidade no seio social.

Nesta perspectiva, aspira-se que a Universidade possa caminhar na concretude dialógica de um Projeto Político Pedagógico, que venha a abrir novas formas de expressão cultural e de linguagens, considerar novas tecnologias no mundo, pesquisas voltadas ao interesse da sociedade, entre outros pontos.

Nesse sentido, nosso país convive entre contradições e conflitos sócio-econômico-político e culturais, onde reina a dependência do conhecimento, fundamentando-se aí forte relação entre "o saber e o poder".

Goergen (1997a) mostra que diante da crise das categorias modernas clássicas do poder (Estado) e do saber (Razão), com desestabilização política e filosófica, na universidade, se instala uma crise de identidade.

Na crise, que ora se apresenta, o Estado por estar a serviço de um novo modelo econômico global, acaba transferindo para os setores privados, suas responsabilidades. E nesse sentido, conforme o que esse autor nos traz, é necessário uma nova fundamentação filosófica e, se está havendo dissociação entre Estado e Universidade, esta necessita de uma reorientação, sendo que a base para a mesma está na avaliação. Não se trata, segundo o autor, de avaliação da performance da universidade (também importante), mas de uma avaliação que traga "para o cam- po da reflexão a transição do modelo de universidade moderna para um novo modelo que ninguém ainda sabe qual será" (Goergen, 1997a, p.64).

\section{A Universidade para o Século XXI}

Portanto; diante da complexidade do final do século, há uma série de problemas que se constituem em desafios para a educação superior, que necessita rever sua missão para atender à sociedade do século XXI, sociedade do conhecimento, da informação e, principalmente, da educação.

Em meio a tantos acontecimentos, parece o momento ideal para pensarmos e repensarmos que Universidade queremos para o século XXI, avaliando o Ensino Superior e a crise na educação, na busca de refletir e definir sua missão hoje e para o novo milênio.

Castro (1997) apresenta perspectivas para a universidade do futuro, segundo discussões da Reunião Anual da "World Future Society" realizada em São Francisco, nos Estados Unidos em julho de 1997, que retomamos neste momento, na forma de apontamentos:

- registro de profissões que terão futuro imediato: genética, meio ambiente, educação física, a comunicação e o apoio espiritual;

- a universidade deverá sofrer mudanças para se adaptar a uma nova sociedade mais ética, moderna e respeitosa;

- maior mudança: maior presença da universidade na sociedade, ultrapassando os limites da oferta de cursos de graduação e de pós-graduação e dedicar-se a cursos de educação continuada; atuar na ajuda e suporte a comunidades carentes;

- preparar-se para receber alunos mais velhos;

- preocupação com sólida formação básica sobre a qual se assentam as especializações;

- as faculdades devem ser rápidas, atendendo às profissões emergentes;

- um dos pontos polêmicos de discussão apontados para a transformação da universidade foi a necessidade de criação de universidades virtuais, utilizando a Internet e outros equipamentos modernos para investir na educação à distância;

- intensificação da dimensão internacional da vida acadêmica;

- polarização crescente entre países desenvolvidos

Paidéia, FFCLRP-USP, Rib. Preto, jan/julho/2000. 
e em desenvolvimento;

- interação, conformando espaços supranacionais, definindo um marco em que serão necessários planos de estudos, de pesquisa e de gestão comuns entre várias instituições;

- revisão de suas práticas de ensino e dos sistemas de informação que utilizam, modificação dos planos de estudos para maximizar sua flexibilização, possibilitando o intercâmbio de estudantes entre instituições, permitindo a mobilidade entre disciplinas e tendo presente a necessidade da educação permanente.

Jorge (1998) apresenta uma proposta de educação universitária como meio de emancipar o homem, como forma de negar um modelo de sociedade que 'coisifica' o homem, transformando-o em mercadoria. Para Adorno apud Jorge (1998, p.172), "a educação não é a moldagem de seres humanos nem a mera transmissão de saber e sim a produção de uma consciência verdadeira, com grande significado político". Nesse sentido, Jorge diz que cabe à escola "reconciliar o cotidiano com a história, o indivíduo com o coletivo, fazendo da esfera pública escolar um locus privilegiado para o aprendizado do debate democrático" (1998, p.173). Assim, a Universidade deve priorizar a formação do homem em construção, nunca a sua reprodução para fins ideológicos de Estado ou de determinados grupos hegemônicos.

Del Masi apud Jorge (1998, p.174) nos remete a refletir sobre o ensinar à nova geração " $n a ̃ o$ tanto como se trabalha, mas como aproveitar bem as horas vagas", no intuito de possibilitar o fruir de um novo bem-estar; "um ensino que possibilite a cada homem se objetivar no processo de conhecimento e transformação da natureza". Nesta perspectiva, Zainko (1999) aponta que o homem, em equilíbrio consigo mesmo e com seu meio, deverá ser o grande desafio para o próximo século. Também seguindo nesta preocupação temos Dennehy apud Apps (1988) argumentando que o propósito da educação deve ser a oportunidade de cada pessoa para desenvolver suas capacidades intelectuais, morais, estéticas e espirituais. Acentuam consequientemente uma educação universitária do indivíduo em sua complexidade e totalidade.

Bustamante (1997) apresenta como grande desafio da educação no século XXI, integrar ciência e tecnologia na esfera do social, uma integração harmônica com a cultura. Sugere que estudos e pesquisas possam estar se desenvolvendo sobre ciência, tecnologia e sociedade, nos currículos do ensino médio, de graduação e de pós-graduação, como forma de se atingir uma sociedade mais humana, justa $e$ solidária, em que a ciência e tecnologia sejam ferramentas fundamentais na promoção de fins socialmente relevantes.

Castro (1997, p.463) nos traz desafios para a Universidade do terceiro milênio, como

"os freqüentes conflitos e rivalidades raciais; a desintegração do tecido social, onde a fome, a miséria e a falta de moradia tornaram-se lugar-comum; o desemprego de longa duração; a poluição do meio ambiente; as disputas $e$ as diferenças dentro dos países e entre países, que culminam em chacinas hediondas, e a corrupção".

Essa autora diz que no caso do Brasil, "dada à mudança de configuração do tecido social, com o envelhecimento crescente da população", uma nova perspectiva se apresenta para a Universidade, 0 atendimento de uma nova clientela, já que se insere em um país que não é predominantemente jovem. Ou seja, é importante pensar em educação para todas as idades, conforme Soria apud Lampert (1997), possibilitando não somente o acesso, mas também a democratização da Universidade, buscando romper no coletivo, as contradições e conflitos que impedem ou dificultam a gestão universitária nessa diretriz.

Para isso, Castro (1997) diz que a gestão da universidade deve se apoiar em relações internas democráticas e relações externas bem organizadas com o Estado e com outras instituições da sociedade, sendo que em nível interno, precisa de pessoas competentes no comando das atividades financeiras, operacionais e didáticas, além, é claro e não menos importante de uma orientação perene para a necessidade de efetiva interação com o conjunto da sociedade.

Xavier (1997) diz que numa sociedade do conhecimento, é importante dividir responsabilidades com todos os segmentos da sociedade e firmar parcerias com instituições de representação de classes e com as organizações não-governamentais 
(ONGs). Da mesma sorte, Zainko (1999) menciona que é necessário a reflexão sobre o papel, nova visão e atividades concretas das instituições de ensino superior, envolvendo além de membros da comunidade acadêmica, membros das ONGs e dos diversos segmentos sociais, caracterizando e justificando propriamente o porquê e a imprescindibilidade da existência da Universidade como legítima representante da história do conhecimento da humanidade.

A Asociación de Universidades Grupo Montevidéo, segundo Castro (1997), aponta para a necessidade de um trabalho conjunto na definição de políticas e estabelecimento de planos e programas e na determinação, definição e solução de problemas de impacto social, ou seja, a proposta de gestão deve ser feita mediante planejamento. A autonomia didático-científica, administrativa e financeira é fundamental para uma boa gestão da universidade. Nos termos que segue, Zainko (1999) sugere um novo pacto universitário em torno de grandes temas: pertinência, qualidade, gestão, financiamento e cooperação internacional. Para a autora há a necessidade de reflexão/ação por meio de três vertentes: (a) expansão do acesso dos sistemas de ensino superior; (b) melhoria da gestão e o reforço de laços com a sociedade; (c) respostas às necessidades de desenvolvimento social.

Castro (1997, p.471) afirma que um grande desafio para a Universidade hoje, é armar-se para ser capaz de contribuir para as grandes transformações do mundo contemporâneo, principalmente sendo "uma instituição aberta para avaliar-se, rever-se e questionar-se, apresentado postura crítica em relação a si, à sociedade e ao Estado". Nesse caminho Carrocci (1997) diz que para dar um salto de qualidade, a universidade, a curto prazo, deve assumir o sistema de auto-avaliação. Zainko (1999) ratifica a importância do auto-conhecimento, proporcionado pela avaliação institucional, estar permeando as ações presentes e futuras.

Para Teixeira (1998, p.101), a Universidade não tem nenhuma verdade a dar, "a não ser a única verdade possivel, que é a de buscá-la eternamente". Nesse sentido, Castro (1997, p. 471) nos remete às afirmações de Moraes e Fischmann que dizem ser

"preciso reafirmar seu compromisso com a cidadania em todos os campos: trazendo des- cobertas para melhoria da qualidade de vida no campo do avanço científico; apresentar-se como locus de discussões, decisões e vivência no processo democrático no campo do aprimoramento democrático, garantindo a produção e difusão do conhecimento e da ciência e permitindo as aluno consolidar um projeto de vida no campo do ensino e cooperando com a fundamentação das mudanças sociais, políticas, econômicas, culturais e tecnológicas, no campo da extensão".

$$
\text { Para Castro (1997, p.472), }
$$

"o acesso à educação superior e aos serviços que ela presta à sociedade é parte e elemento de qualquer programa de desenvolvimento sustentável, pois o desenvolvimento de recursos humanos e da pesquisa é condição para que a humanidade possa enfrentar os desafios deste final de século e entrar no terceiro milênio com a garantia da educação e formação dos cidadãos, a nivel mundial".

Segundo Castro (1997) é necessário que cada universidade busque sua própria qualidade dentro de suas possibilidades e limites procurando aperfeiçoar dia-a-dia, seu sistema de ensino e de pesquisa, mantendo-se bem adaptado ao contexto mundial, regional, local. Esta qualidade também é referida por Zainko $(1999$, p.25) como busca fundamental e como principal norte da gestão universitária "que deve de forma multidimensional abranger todas as principais funções do ensino superior", isto em termos de acesso, currículo, infra-estrutura e "da capacidade de respeito aos princípios da liberdade acadêmica e de autonomia institucional".

Ainda de acordo com Castro (1997), a universidade deve consolidar e fortalecer os valores de cidadania; deve praticar o diálogo universal, ajudando o país a se inserir bem no mundo globalizado. Nesse sentido, Zainko (1999) aponta para o 'entendimento intercultural', condição de cooperação mais efetiva entre instituições nacionais e internacionais.

Nessa aproximação com outras realidades, Welch (1997) nos traz que a educação superior pode ter um importante papel a representar no rompimento de barreiras culturais, onde o debate deve aconte- 
cer, assim como a internacionalização do pessoal acadêmico. Papéis também relevantes estão relacionados com a formação de opinião e cultivo de futuros líderes na sociedade.

Podemos observar pela fala de professores e pela análise da literatura que as instituições ainda não estão certas sobre qual deverá ser seu papel, e nesse sentido faz-se importante, segundo Pereira (1999, p.19) que a universidade procure "recuperar a audácia de se questionar, deve relativizar sua função mediadora das necessidades imediatas da sociedade e se lançar no projeto de construir utopias relativas ao que deve ser sua função". Também Goergen (1999) aponta para a necessidade da universidade repensar sua identidade na perspectiva de um novo cenário que ora se apresenta. Nesse sentido esse autor retoma a questão do grande déficit de reflexão que a universidade tem sobre si mesma e é tal postura que dificulta sua orientação quanto à sua missão e desenvolvimento.

Compartilhando dessa opinião Johnston (1998) e Carrocci (1997), dizem que a universidade deve ampliar a visão da produção do conhecimento como um fornecedor centrífugo e centrípeto, para tornar-se um parceiro nos contextos nacionais e internacionais, desta forma observam que há que se reunir alguns pontos importantes para discutir o quadro da Universidade nos dias de hoje e, depois de análise e reflexão, tentar metas para o futuro: situação financeira; autonomia universitária; situação e reavaliação de docentes; situação profissional dos funcionários; nível de transmissão de conhecimento (graduação e pósgraduação); situação da extensão universitária, da prestação de serviços; qualidade dos serviços; produção científica e pesquisas; situação dos aposentados; satisfação da sociedade e mercado com os profissionais que estamos formando. Para esses autores, a Universidade deverá estar atuando como zeladora, geradora e transferidora de conhecimento, oferecendo condições de igualdade e de chances para todos, daí a sua ação centrípeta e centrífuga.

Para Funari (1997), a Universidade tem que se dedicar a estudos que possam dialogar com a ciência mundial, como matemática pura, física básica, sânscrito e, para tanto, faz-se necessário não dissociar ensino e pesquisa. Enfatiza que não basta a democratização da academia, pelo fato de que ela depende da democracia da sociedade brasileira, conseqüente- mente

"o compadrio da Universidade não é senão infima parcela de um sistema social paternalista. É necessário mudá-lo, para que se mude a Universidade, mas a própria academia é um campo privilegiado de luta pela reforma social, pois como vimos, sem ciência não há desenvolvimento e não há ciência com compadrio" (Ibidem, p.55).

Keim (1996), analisando a educação excludente às vésperas do próximo milênio, diz que é preciso que os educadores tenham compromisso com a expansão da vida, para que possam reagir contra os agentes animadores dos referenciais da sociedade atual, tal como o fato de que vidas biológicas, afetivas e sociais possam ser sacrificadas para se manter hegemônicos o mercado, as instituições e os contratos. Vale citar Assmann apud Keim (1996), quando anuncia que a população mundial, no ano 2010 , estará em torno de sete bilhōes de habitantes e o mercado de trabalho atenderá entre $\mathbf{6 0 0}$ milhões a um bilhão de habitantes. O que se pretende fazer para que essa massa excluída tenha condições mínimas de sobrevivência, de alimento; afeto, abrigo e ocupação digna? Diante desse desafio, esse autor nos remete a refletir sobre a importância da Bioética, fazendo parte dos estudos, sobre condições de vida na sociedade e nos ambientes naturais, como viga mestra, "sem deixar que ela seja vulgarizada e esvaziada como foi a Ecologia" (p.107).

Keim (1996) apresenta uma proposta alternativa, para análise de nossa ação e postura educativa, de educação construtiva e transformadora, a serviço de determinado propósito coletivista, que apoia o processo educativo no contexto no qual a ação em estudo está inserida, promovendo a construção de conhecimentos, sentimentos e procedimentos significativos para a vida, ficando o treinamento indicado apenas para as partes do processo em que ele é imprescindível. Busca-se uma postura voltada para a construção dos conhecimentos ou para a transformação das relações humanas, estando sempre presente a ética, intermediando as ações humanas e sociais Esta postura, traduzida como humanismo radical, segundo o autor busca 
"a radicalidade exigida pela vida, numa perspectiva de construção de conhecimentos, sentimentos e comportamentos que tenham como finalidade uma vida farta, manifesta como afeto, abrigo, ocupação e alimento em quantidade e qualidade suficientes para manter viva a dinâmica organizativa da sociedade, dos ambientes e das relaçōes entre todos os viventes $e$ ambientes nos quais interagem". (Keim, 1996, p.111)

Portanto, para Keim (1996, p.112), a educação que queremos deverá estar em harmonia com o humanismo radical, "para que se tenha esperança de vida plena em sociedade fraterna". Trazemos neste momento, Escotet (1990), quando afirma que é necessário um novo renascimento da cultura, uma nova filosofia política, social e econômica que desenvolva novos paradigmas, que tornem mais real a aproximação com a liberdade, igualdade e solidariedade entre os homens.

Alguns autores citam a preocupação com a não transmissão de conhecimentos, mas a orientação no sentido do aluno buscar o conhecimento, ser capaz de selecioná-lo e interpretá-lo no intuito de poder solucionar problemas; trata-se de criar no homem a capacidade de antecipar o futuro, arriscar-se a pensar, seguir aprendendo permanentemente.

Para Benito (1998) a Universidade deverá enfrentar os "anseios" da sociedade pós-moderna, pensando num saber curricular que venha a atender a uma perspectiva pluralista. Nesta perspectiva, deverá propor novos conceitos e metodologias para o sistema educativo, considerando as influências da tecnologia do mundo, as contribuições dos valores culturais e o jogo das novas linguagens, com pesquisas voltadas ao interesse de toda a sociedade. Para esse autor a educação deve, através da definição do perfil dos cenários do futuro em relação ao pluralismo educativo, responder a algumas questões e problemas que se apresentam, como forma de orientar a teoria e a prática pedagógica.

Featherstone (1999) também coloca sua preocupação na questão da comunicação entre as pessoas que estão do lado de "dentro" e do lado de "fora" da Universidade, para tal, alerta para que não estejamos desinteressados sobre a nova tecnologia da comunicação, comunicar é viabilizar processos, é encontrar caminhos possíveis e legítimos para uma Universidade verdadeiramente pluralista e preocupada com o presente e futuro do homem. Escotet (1990) retrata que o desafio didático, para transformar as estratégias de aprendizagem, constitui um dos problemas centrais da educação na universidade hoje, quando abrimos as.portas para o século XXI. $O$ autor nos conduz a refletir que talvez seja necessária uma mudança que exija a retomada da imagem renascentista daqueles homens sobre os quais não se sabia 'onde terminava o artista e onde começava o cientista': Em se tratando de mudanças e inovações, estas requerem currículos flexíveis, que possibilitem ao aluno enfrentar desafios; exigem aprendizagem e reaprendizagem profundas; as mudanças do indivíduo serão no sentido de solucionar problemas, manter-se informado, assumir novos papéis e revelar comprometimento com aquilo que faz.

A fragmentação das relações, dos currículos do conhecimento não é mais suportável, como aponta Dias Sobrinho (1998, p.27): "Até mesmo para o mercado, ou seja, até mesmo para os interesses exclusivamente econômicos, a especialização e o parcelamento exagerados dos campos do conhecimento e das áreas de habilidades se tornam hoje, inadequadas".

A Lei de Diretrizes e Bases da Educação Nacional do Brasil (artigo 53, inciso II) aponta para a possibilidade de revisão de currículos e para tal a comunidade acadêmica deverá usar de criatividade e num trabalho coletivo discutir e implementar propostas que visem atingir um perfil adequado do formando que estará atuando nos próximos anos, ou seja, no próximo milênio.

Johnston (1998), apoiado em Barnett, diz que os estudantes devem ser encorajados a um comportamento de aprendizagem independente e autônomo, sendo necessário capacidade crítica para assimilar e acomodar as novas mensagens.

Nesse sentido, de acordo com Marques (1998, p.100), o currículo deve "oferecer as experiências de aprendizagem que reforcem os conhecimentos e habilidades indispensáveis ao cidadão em suas dimensões de pessoa e de profissional engajado em seu tempo". A autora apresenta categorias imprescindíveis na formação do aluno: auto-conhecimento, habilidades básicas, relacionamento interpessoal, solução de problemas, visão de contex- 
to, ação inteligente; a tônica desta proposta de currículo é a interdisciplinaridade, que deve ser planeja$\mathrm{da}$, replanejada e desenvolvida pela universidade junto com os alunos.

Quanto à formação de estudantes, Escotet (1990) diz que uma das chaves para resolver o dilema entre formação generalista e especialista é a integração das duas.

Segundo Marcel Bonvalet apud Escotet (1990) a universidade do futuro deverá ter um papel criativo, flexível e libertador, tanto em produção de alternativas e de consciência crítica, oferecendo uma formação flexível e criativa.

Não poderíamos deixar de resgatar através de Boaventura Santos (1987, p.34), conceitos fundamentais para serem apreciados em nível de reflexão, como o paradigma emergente, "concepção de conhecimento como espaço conceitual, no qual aluno $e$ professor constroem em saber novo, produto sempre contraditório de processos sociais, históricos, culturais e psicológicos" e, através de Lucarelli apud Cunha (1998, p.24), práxis inventiva, "produção de algo novo no aprendizado, através da resolução intencional de um problema, que pode ser tanto de indole prática como puramente teórica".

Para Boyer apud Jonhston (1998), o desafio do próximo século não é somente a descoberta do conhecimento, mas o acesso e adaptação às descobertas em amplos padrões e perspectivas.

Ainda de acordo com Johnston (1998), é preciso manter as prioridades definidas por Boyer: a descoberta para evitar estagnação, ensino para evitar descontinuidade, aplicação para evitar irrelevância e integração para evitar pedantismo.

Delors et al. apud Xavier (1997, p.299) afirmam que num processo de educação nacional, devese propiciar a cada indivíduo, quatro vias de aprendizagem:

\footnotetext{
"o aprender a conhecer (para adquirir os instrumentos de compreensão), o aprender a fazer (para agir no meio em que vive), o aprender a viver em sociedade (para participar $e$ cooperar com os outros), 'o aprender a ser (integração das vias anteriores e desenvolvimento total da pessoa: espirito, corpo, inteligência, sensibilidade, sentido estético, responsabilidade pessoal, espiritualidade)".
}

Para Marques não importa mais a acumulação de conhecimentos, mas a seleção e utilização do mesmo para adaptação no mundo em rápidas transformações. Ainda de acordo com Delors et al. apud Xavier (1997, p.301), "o conceito de educação durante toda a vida é a chave que abre as portas do século XXI". Também nesse sentido, Correia apud Xavier (1997, p.301) aponta para que este conceito ultrapasse "a visão tradicional e a separação entre educação inicial e capacitação contínua ou educação em serviço, que dão a idéia de atendimento de necessidades pontuais". O propósito de educação ao longo da vida é "o da sociedade educativa, onde tudo pode ser ocasião para aprender e desenvolver os próprios talentos" (Delors et al. apud Xavier, 1997, p.301), onde "o homem com seu potencial de aprendizagem e desenvolvimento, deve aproveitar todas as oportunidades oferecidas pela sociedade" (Xavier, 1997, p.301). Nesse sentido, Escotet (1990) diz que a Universidade deve passar de uma educação terminal para uma educação permanente; permanente no sentido de acompanhar toda a vida do homem. Será uma verdadeira revolução na educação e, a missão da universidade será de fortalecer as estruturas de pós-graduação, estender a atuação formativa à atuação profissional, compartilhar experiências e capacitação com o sistema produtivo.

Nessa via Escotet (1990) prevê que isto só será possível se houver transformação radical das estruturas tradicionais da universidade e da escola. Vê-se então a necessidade de uma nova filosofia de educação e para atender a ela é necessário uma nova estrutura e administração universitária. Nesse rumo de transformações radicais, Apps (1988) refere-se à importância de, em uma sociedade em aprendizagem, se proceder com o exame de propósitos e explicitação da declaração da missão, o que pode e muito, ajudar a instituição a considerar como deve responder às mudanças sociais e às demandas desta sociedade. Neste caminho também aponta Welch (1997) quando nos traz que situações problemáticas ocorrem no momento em que posições epistemológicas, pedagógicas e outras não são examinadas e reexaminadas, à luz dos novos tempos.

Dias Sobrinho (1998, p.27) diz que "o grande desafio consiste em educar para uma sociedade que ainda nāo existe". Para tal é imprescindível a "capacidade de se estar em condições de aprender e 
construir novos conhecimentos".

Em se tratando das universidades do Cone Sul, Leite (1998, p.298) indica que as Universidades precisam cumprir seu papel, "produzindo mais e mais compreensões, sobre os povos e culturas desta parte do mundo, dentro dos paradigmas do conhecimento que vão além do espaço micro, projetando-se para análise de realidades macrossociais". A autora afirma ainda, que a utopia do século XXI baseia-se na integração como idéia, no mundo de sociedades que ela envolve, "presidido por políticas inteligentes de negociação e cooperação... Pode e deve ser, também, a realidade que vai alimentar a produção da pesquisa.e mexer com a Universidade". (Leite, 1998, p.298)

Teixeira (1998, p.88) afirma que a função da Universidade não se restringe a somente difundir conhecimentos, conservar a experiência humana, preparar práticos ou profissionais de ofícios ou artes, mas trata-se de manter uma atmosfera de saber vivo e não morto, de "formular intelectualmente a experiência humana, sempre renovada"; trata-se de difundir a cultura humana, de criar uma atmosfera que cultive a imaginação, cultivando a capacidade de dar sentido e significado às coisas.

Goergen (1997b, p.28) nos diz que na medida em que a nossa sociedade está se tornando a sociedade do conhecimento, faz-se urgente "reinventar uma ética social e coletiva que zele pela educação da razão em sentido mais abrangente, que não inclui apenas o teórico (a ciência) mas também o prático (as relações dos homens entre si e com a natureza)", já que o sentido da razão foi perdido ao longo da modernidade.

\section{Buscando revelar nossa realidade: UEL e ÚNICAMP}

Procuramos neste momento do trabalho, obter contribuições de professores pesquisadores das Universidades Estaduais de Londrina e de Campinas (UEL e UNICAMP), na forma de depoimentos, como uma maneira de captar a visão de membros de nossa comunidade universitária.

Para tal elaboramos (Anexo 1) uma questão norteadora para a elaboração dos depoimentos: "Pontos/estratégias consideradas fundamentais para o planejamento da universidade do próximo século". Estas correspondências foram entregues a 10 (dez) professores, sendo 3 (três) da UEL e 7 (sete) da
UNICAMP, por nós escolhidos. Obtivemos retorno de 7 (sete) depoimentos, que se encontram retratados na íntegra, com autorização dos professores, no Anexo 2. A intenção foi de buscar na experiência vivida por nossos professores, idéias e sugestões enriquecedoras que se entrelaçassem com os autores por nós consultados.

Iniciaremos com Berbel que diz para que a universidade do século XXI deve dar mais atenção ao desenvolvimento de seus alunos, em termos de hábitos acadêmicos e sociais, e para tal deverá investir nos professores para que sejam muito mais do que apenas informadores. Essa professora registra que o papel do professor seja de "provocador, desafiador do potencial do aluno e da construção do conhecimento", por meio das atividades fins da universidade: ensino, pesquisa e prestação de serviços à comunidade. Sua ênfase está no desenvolvimento dos recursos humanos para atender à universidade do próximo milênio.

Já Bertan, em seu depoimento, diz que a universidade deve responder aos desafios da modernidade, da ciência, da técnica, da cultura e da cidadania, estando aberta e ajustando-se com competência. Para tal é necessário que desenvolva o pensamento crítico-social. Para esse professor, através da pesquisa científica e tecnológica, a produção de novos conhecimentos fortalecerá a sociedade, no sentido de que se tome mais humana, justa, democrática e solidária.

Fiorentini refere-se a duas estratégias. A primeira diz respeito à existência de um referencial de planejamento e ação da universidade, que deve partir, "do mundo do trabalho contemporâneo, a vida social e cultural emergente". Há necessidade da universidade perder a arrogância e prepot6encia com relação ao saber sobre as coisas da vida, sendo imprescindível para ela, aprender a ouvir e conhecer melhor a vida do trabalho e das relações humanas. Como segunda estratégia, Fiorentini relata a importância de envolver membros da universidade e da sociedade para que repensem coletiva/dialógica e reflexivamente a universidade; repensem sua função social, seu planejamento, mudanças e ações. E, nesse sentido indica algumas ações: produção de novos conhecimentos, desenvolvimento de novos modos de produção de conhecimento e de intervenção no modo de vida e o repensar a formação de novos profissio-

Paidéia, FFCLRP-USP, Rib. Preto, jan/julho/2000. 
nais na perspectiva de uma formação contínua ou do desenvolvimento profissional.

Para o professor Goergen, a universidade deverá encontrar um novo equilíbrio na revalorização do regional, do local e do cultural. Aponta para que a universidade deva assumir uma forma bimodal (universidade de presença e à distância); deverá ter mais flexibilidade e mobilidade; deverá assumir posição ante a ciência moderna predadora; não poderá defender um modelo de ciência falocêntrico; deverá buscar equilíbrio entre o local e o global. Assim como a ciência, a universidade para Goergen deverá estar preocupada com a ecologia, a paz, a moral, o humano. Diz que é preciso ter uma visão de complexidade do real, com introdução do princípio da incerteza.

Conforme o solicitado, Pereira apresenta pontos e estratégias essenciais para o planejamento da universidade do próximo milênio, que listaremos na íntegra, a seguir.

\section{"Pontos.}

- ser local ao mesmo tempo que global;

- estrutura flexivel e comprometida a participar cooperativamente na busca de solução para questões locais, regionais, nacionais e internacionais;

- ter como objetivo uma formação mais geral que profissional;

- ser menos voltado para o mercado e menos burocrático;

- deixar de ser 'uma federação' de escolas profissionais;

- deixar de considerar a cultura humanística como 'ornamental' e passar a considerá-la como fundamental elou eixo condutor de atividades profissionais;

- substituir o treinamento para um 'saber fazer' por uma postura de pesquisa intelectual - reflexão crítica em relação àquilo que se faz;

Estratégias:

- tempo de permanência na universidade mais estendido para que o aluno não freqüente só as aulas, mas também o ambiente cultural da universidade;

- redefinir a idéia de 'democratização do ensino';

- preparar para uma sociedade não mais em equilíbrio;

Paidéia, FFCLRP-USP, Rib. Preto, jan/julho/2000.
- não insistir numa transmissão e treinamento de habilidades mas no desenvolvimento do conhecimento;

- substituir a estrutura administrativa

departamental;

- renovar aspectos institucionais."

A professora Pereira, de uma forma geral, vê a universidade do futuro aberta para as questões mais amplas, tanto em termos de formação como de interação com o mundo (relações internas e externas), aponta para a flexibilidade e para a desburocratização da universidade.

Finalmente, o professor Prota refere-se a três pontos que podem ser amplamente desdobrados: privilegiar o binômio investigação científica $x$ humanidades; a formação profissional pode ser oferecida em instituições ligadas ao setor produtivo fazendo ou não parte da universidade; num novo modelo acadêmico há a necessidade de centralizar as atividades da universidade numa pró-reitoria de pesquisa e de pós-graduação, em torno da qual se estabeleceriam as atividades de ensino e de extensão.

Foi possível observar que a fala dos professores que estão fazendo parte de nossa realidade universitária assemelha-se ao exposto anteriormente, através do levantamento bibliográfico. Na verdade são formas diferentes de ver o assunto, no sentido de revelar a ansiedade que todos temos na busca de uma universidade cada vez melhor

\section{Alinhavando algumas conclusões}

Acreditamos que é possível extrair da crise, elementos passíveis de reflexão e que nos façam, comprometida e coletivamente, ousar e construir uma nova identidade para a Universidade, em termos de mudanças não só de paradigmas curriculares, de processo ensino-aprendizagem, mas principalmente de avaliação e gestão universitária. A mudança de cultura, construção difícil e imprescindível neste momento, deve-se dar no sentido do desenvolvimento do homem, como ser humano e solidário, num ir e vir, num movimento dialético. $\mathrm{O}$ trabalho coletivo faz-se necessário, já que isoladamente ficamos, muitas vezes, impedidos de enxergar e de criar.

Não queremos a estagnação da universidade, dela própria enquanto instituição, nem de seus membros que formam uma comunidade, no sentido pleno da palavra; queremos uma instituição forte e 
com forte vinculação com a comunidade. Queremos uma universidade em contínuo fazer-se, cujo modelo ideal será o que almejarmos, o que buscarmos, o que vamos inventar e construir.

É bom frisar que o ideal de Universidade para o século XXI, que ora se apresenta, não é algo acabado e fechado como receita para a otimização da universidade que se deseja, entretanto, como objeto processual que se constrói a medida que as necessidades humanas que vão requerendo conhecimentos mais avançados de acordo com a sua realidade social/econômica/política, caracterização maior "locus universitário".

É preciso romper com a estrutura burocrática, fragmentada, departamentalizada da Universidade, e fazer nascer algo da base para o topo na hierarquia universitária. Queremos uma Universidade que forme seu quadro de professores comprometidos com trabalho de criar, inventar, reinventar o processo de conhecimento e que possam de forma crítica e autocrítica fazer parte do seu quadro de dirigentes.

Em se tratando da construção do projeto político pedagógico, sua relevância não deve ser assumida como modismo, mas como elemento fundamental de construção e sustentação das ações da comunidade acadêmica e também de uma nova universidade que ousou submeter-se à necessárias transformações, a começar pela reflexão e questionamento de suas metas e alcances. Mas não é possivel, a nosso ver, falar de projeto político pedagógico sem falar de avaliação. Nesta construção três eixos podem ser ponto de partida de discussões: intencionalidade da Universidade, concepção de ciência e concepção de currículo, pontos esses que arrolamos no discorrer desse trabalho. Entretanto, de forma concreta, que relações a Universidade deve desenvolver com a sociedade e de quais formas?

Através da pesquisa que efetuamos a concluímos que a Universidade "deverá ser" o local onde se instale permanentemente a reflexão, perante a aváliação e a qualidade, num esforço coletivo e participativo, com ações educativas necessárias para cumprir seus propósitos.

Entre os propósitos da Universidade, não podemos deixar de ratificar a importância da associação entre a trilogia ensino, pesquisa e extensão, onde um alimenta o outro e da construção do conhecimen- to, através de sucessivas reconstruções do saber.

Da mesma maneira, é importante que o professor universitário pense na superação do existente, do cotidiano, do pronto, do fechado, do enjaulado, procurando concretização e compromisso na busca da emancipação individual e coletiva. É preciso lutar para não permitir a desmoralização da Universidade, pois se o modelo atual não está bom, devemos buscar a conștrução do modelo que pensamos ser mais adequado e viável à nossa realidade.

Nesse sentido, cabe ao professor e a toda a comunidade universitátia e autoridades políticas acompanharem e participarem efetivamente da aceleração das mudanças que estão ocorrendo no mundo e que afetam de forma direta a vida social. Há que fomentar caminhos, propostas, iniciativas para que a Universidade seja propriamente integrada e útil à sociedade.

Propostas inteligentes e ousadas têm sido colocadas em prática nessa diretriz, desde as propostas de alteração curricular, com implantação do Problem Based Learning (PBL) - Aprendizagem baseada em Problemas, até metodologias inovadoras do ensino, como a Metodologia da Problematização. Seja qual for o nome desta fabulosa fórmula de agregar o desagregado, o importante é que o conhecimento seja trabalhado hologramaticamente, em sua unicidade, algo visando a transdisciplinaridade.

A Universidade não está falida, está desacreditada, acomodada e, estão fora de rotina alguns valores extremamente significantes, que precisam ser retomados, pois precisamos ter sempre em mente uma idéia renovada de Universidade.

Vale trazer a mensagem de Saviani (1986, p.84) quando nos diz que

"Se não há mais razão para trabalharmos em educação, animados de um entusiasmo ingênuo, também não há razão para nos paralisarmos num pessimismo igualmente ingênuo. Há muita coisa que não apenas pode como deve ser feita. É hora, pois, de nos lançarmos ao trabalho com entusiasmo; entusiasmo critico, porém."

Sabemos que a Universidade tem sobrevivido, mas queremos que daqui para frente ela viva, superando os reveses e o desequilíbrio de uma histó-

Paidéia, FFCLRP-USP, Rib. Preto, jan/julho/2000. 
ria tateante, e se construindo a cada dia portando o elo maior da consciência de si e do mundo em dinâmica transformação, pontos basilares do que chama viver em sentido pleno.

A consciência de si e do mundo favorecerá à Universidade encontrar sua própria identidade e conduzir-se num perene policiamento dialético, por essa via, faz-se imprescindível a avaliação institucional, permeando e dando suporte a todas as suas atividades.

Tudo isto é um convite, convite ao uso de nossa criatividade, disposição, entusiasmo, raciocínio e inteligência.

Acreditamos, pela dialética existente na própria natureza, como apontado no trecho de Renato Teixeira no início desta pesquisa, que a cada dia, é preciso amanhecer, construindo algo novo e precioso, algo que tenha luz e que esta luz possa iluminar o caminho do ser humano.

Devemos trabalhar muito HOJE, para construirmos a nova Universidade, a Universidade do futuro que começa agora.

Esperamos que estas reflexões, sobre a nova missão e identidade para a universidade, desencadeiem discussões em nossas instituições de ensino, mas que não permaneçam apenas como 'sonhos' ou 'utopias', e sim apontem para um exercício prático, que através de todos nós, possam ir se concretizando de agora, 2000 , crescendo e rasgando o próximo século.

\section{Referências Bibliográficas}

Apps, J.W. (1988). Higher education in a learning society: meeting new demands for education and training. San Francisco: Jossey Bass Publishers.

Belloni, I. (1992). Função da Universidade: notas para reflexão. Universidade Educação. São Paulo: Papirus.

Benito, E.A. (1998).La Educación ante los escenarios de fin de siglo. Educação Brasileira, 20(40), 28-35.

Bustamante, J. (1997). A integração da ciência, tecnologia e sociedade: o grañde desafio da educação no século XXI. Educação Brasileira, 19(39), 11-20.

Carrocci, L.R. (1997).Universidade rumo ao terceiro milênio. Revista da Faculdade Salesiana, 35,

Paidéia, FFCLRP-USP, Rib. Preto, jan/julho/2000.
42-45.

Castro, M de. (1997). Gestão de universidades do terceiro milênio: alguns desafios e perspectivas. Ensaio: Avaliação de Políticas Públicas Educacionais, 5(17), 463-476.

Cunha, M.I. da. (1998). O professor universitário na transição de paradigmas. Araraquara: JM Editora.

Cunha, L.A. (1988). A universidade reformada: $o$ golpe de 1964 e a modernização do ensino superior. Rio de Janeiro: Francisco Alves.

Dias Sobrinho, J. (1998). O ensino de graduação e a pesquisa: construção e reconstrução do conhecimento e sociedade. Avaliação, 3 , n.3 (9), 21-30.

Dreze, J. \& Debelle, J. (1983). Concepções da universidade. Fortaleza: Universidade Federal do Ceará.

Escotet, M.A. (1990). Vision de la universidad del siglo XXI: dialectica de la mision universitaria en una era de cambios. Revista Española de Pedagogia, n.186, 211-228.

Fávero, M.L.A. (1997). A universidade brasileira em busca de sua identidade. Rio de Janeiro: Vozes.

Featherstone, M. (1999). Da universidade à pósmodernidade? Explorando as possibilidades de novas formas de comunicação. Em: E.M.A. Pereira \& J.C. dos Santos Filho (Orgs.), Universidade na Pós-modernidade. No prelo.

Freitas, J. de (1985). Universidade 2000. Belo Horizonte: Litera-Maciel.

Funari, P.P. (1997). A universidade brasileira rumo ao terceiro milênio. Revista Adusp, 52-55.

Goergen, P.L. (1997a). A avaliação universitária na perspectiva da pós-modernidade.Avaliação, 2(3), 53-65.

Goergen, P.L. (1997b). A ciência como política: fragmentos filosóficos para a formação do cientista. Estudos em Avaliação Educacional, pp.5-29.

Goergen, P.L. (1999). A crise da identidade da universidade moderna. Em: E.M.A. Pereira \& J.C. dos Santos Filho (Orgs.), Universidade na Pósmodernidade. No prelo.

Johnston, R. (1998). The university of the future: Boyer revisited. Higher Education, 36, 253-272.

Jorge, M.T.S. (1998). Será o saber escolar supérfluo 
no mundo das novas tecnologias? Educação $e$ Sociedade, 19(65),163-178.

Keim, E.J. (1996). Que educação queremos para iniciar o próximo milênio? Revista Educação e Ensino - USF, Bragança Paulista, 1(2), 99-113.

Lampert, E. (1997). O Mercosul e a Universidade no século XXI. Pró-Posições, 8(1), 5-15.

Lauand, L.J. (1987), O que é uma universidade? São Paulo: Perspectiva.

Leite, D. (1998). Universidade e Integração: A centralidade do conhecimento. Em: M.C. Morosini (Org.), Universidade no Mercosul (pp.291-298). 2.ed. São Paulo: Cortez.

Luckesi, C.C. et al. (1991). Fazer universidade: uma proposta metodológica. 6. ed. São Paulo: Cortez.

Marques, J.C. (1998). Uma concepção de currículo para moldar o futuro. Educação Brasileira, 20(40), 93-105.

Morais, J.F.R. de. (1992). Universidade: seus desafios neste final de século. Pró-Posições, 3(8), n.2.

Nunes, R.A.C. (1979). História da Educação na Idade Média. São Paulo: EPU/EDUSP, p. 212.

Pereira, E.M.A. Pós-modernidade: Desafios à universidade. Em: E.M.A. Pereira \& J.C. dos Santos Filho (Orgs), Universidade na Pósmodernidade. No prelo.

Pereira, O.J. (1990). Aristóteles: o equilíbrio do ser. São Paulo: FTD.

Ricoeur, P. (1983). Prefácio. Em: J. Dreze, \& J. Debelle (Orgs), Concepções da universidade. Fortaleza: Universidade Federal do Ceará.

Santos, B. de S. (1987). Um discurso sobre as ciências. Porto, Portugal: Afrontamento.

Sucre, M.G. \& González, L.F.M. (1994). Qué és una universidad? Em: A. Lovera (Org.), A. Reconversión Universitaria. Caracas: Fondo Editorial Trópykos.

Teixeira, A. (1998). A universidade de ontem e de hoje. Rio de Janeiro: EDUERJ.

Ullmann, R. \& Bohnen, A. (1994). A universidade: das origens à renascença. São Leopoldo: Ed. Unisinos.

Wanderley, L.E.W. (1991). O que é universidade.
8. ed. São Paulo: Brasiliense.

Welch, A.R. (1997). The internacionalization of the academic profession. Higher Education, 34(3), 323-345.

Xavier, O.S. (1997). A educação no contexto das mudanças. Revista Brasileira de Estudos Pedagógicos, 78, n. 188/189/190, 285-304.

Zainko, MA.S. (1999). A gestão do ensino superior e os desafios da sociedade do conhecimento, da informaçăo e da educação. Avaliação, 4(11), n.1,23-26.

\section{ANEXO 1 \\ "PONTOS/ESTRATÉGIAS CONSIDERADAS FUNDAMENTAIS PARA O PLANEJAMENTO DA UNIVERSIDADE DO PRÓXIMO SECULO"}

\section{ANEXO 2 \\ Depoimentos dos Professores da Universidade Estadual de Londrina (UEL) e da Universidade Estadual de Campinas (UNICAMP)*}

\section{Depoimento $n^{\circ} 01$}

"Para o século XXI, a universidade deve estar aberta e se ajustar para responder com competência aos desafios da modernidade, da ciência, da técnica, da cultura e fundamentalmente da cidadania.

Deve desenvolver o pensamento crítico-social sobre as transformações que estão ocorrendo, com o objetivo de avaliar o que é válido ou não.

Deve produzir novos conhecimentos, através da pesquisa científica e tecnológica, que venham contribuir para o fortalecimento de uma sociedade mais humana, justa, democrática e, numa palavra, solidária." Prof. Dr. Levino Bertan -Depto de Educação-Centro de Educação, Comunicação e Artes - UEL

\section{Depoimento $n^{\circ} 02$}

"A universidade deverá dar mais importância à aprendizagem dos alunos, ao seu desenvolvimento intelectual, para além da aquisição de conhecimentos (memorização), ao seu desenvolvimento em termos de atitudes e hábitos acadêmicos e sociais. Para isso,

\footnotetext{
*A publicação dos nomes dos depoentes abaixo é de responsabilidade do autor, que declara possuir autorização por escrito das pessoas $\mathrm{p} /$ as sim proceder.
}

Paidéia, FFCLRP-USP, Rib. Preto, jan/julho/2000. 
a universidade deverá investir nos seus recursos humanos - os professores, para que além de especialistas em suas áreas específicas profissionais, tenham preparo para ser professores/educadores e não apenas informadores.

Os recursos tecnológicos têm ampliado as chances e fontes de aquisição de informações além das anteriormente disponíveis. $\mathrm{O}$ professor tem que aprender seu papel de provocador, desafiador do potencial do aluno e da construção do conhecimento, através do ensino, da pesquisa e da prestação de serviços à comunidade, dai dever ser preparado para isso.

De nada adiantará uma universidade altamente moderna em termos de equipamentos, se seus recursos humanos forem improvisados, despreparados."

Profa. Dra. Neusi Aparecida Navas Berbel - Depto de Educação-CECA - UEL

\section{Depoimento $n^{\circ} 03$}

"Tradicão profissionalizante sem a correspondente tradição de formação humanista, é a visão que temos como sendo a raiz da crise da Universidade brasileira.

É imprescindível que se volte a privilegiar o binômio investigação científica/humanidades. Hoje o docente define-se pela capacidade de produção própria do conhecimento e o discente deve estar envolvido nessa atividade produtiva; para tanto há necessidade de uma sólida formação humanista.

Quanto à formação profissional, seria oferecida em institutos que mantém uma relação mais estreita com o setor produtivo; esses institutos poderiam fazer parte da universidade ou permanecerem isolados.

Em lugar de uma Universidade de ensino teríamos uma universidade que privilegia a investigação científica como inspiração fundamental e a formação humanista como atividade essencial e específica.

Ao falar em privilegiar a investigação científica há necessidade de distinguir entre a figura do docentepesquisador e a do pesquisador profissional. A pesquisa profissional tornou-se muito cara, hoje em dia, e é sempre mais difícil para a Universidade suportar investimentos onerosos. Esse tipo de pesquisa está sendo acampado por Institutos de pesquisa, que, às vezes, não tem nada a ver com a Universidade. Para a Universidade, sem recusar pesquisadores profissionais, é desejável o docente-pesquisador, que poderá dedicar-se, de maneira mais adequada, também para atividades de unificação dos resultados obtidos por pesquisadores profissionais e, portanto, realizar sínteses didáticas e sínteses culturais.

Ensino. Pesquisa e Extensão, trinômio apregoado como indissociável, tornou-se slogan publicitário, sem conseqüências práticas: a Pró-Reitoria de Ensino de Graduação, a de Pesquisa e Pós-Graduação e a de Extensão realizam atividades independentes, desvinculadas da visão da Universidade moderna.

É imprescindível que o novo modelo acadêmico sugerido pelas considerações anteriores seja espelhado num modelo administrativo em estreita conjunção com o acadêmico: optar pela Pró-Reitoria de Pesquisa e Pós-Graduação dando suporte e inspiração a duas Coordenadorias, de Ensino de Graduação e de Extensão, integradas à Pró-Reitoria tanto no planejamento quanto na execução e avaliação dos resultados. Só assim, pode-se estabelecer uma política de Pesquisa e Pós-Graduação, que vise a melhoria do ensino de graduação e a disseminação de resultados para a comunidade. A mesma inspiração e os mesmos critérios deverão orientar a escolha de representantes nos colegiados.

Outro ponto de reflexão é a necessidade de implementar uma política de formação profissional (para quem completar o ensino médio) em institutos fora da Universidade. A fatídica tradição de formação de 'doutores', bem como o mito da democratização da Universidade devem ter vida curta."

Prof. Dr. Leonardo Prota -Depto de Filosofia - Centro de Ciências Humanas - UEL

\section{Depoimento $n^{\circ} 04$}

"A nova legislação educacional parece Ter dado um grande impulso aos centros universitários e às faculdades isoladas; pelos anúncios na mídia, vemos o aparecimento de muitos cursos superiores voltados direta e exclusivamente para o mercado de trabalho. Esses cursos e instituições ao se dedicarem exclusivamente ao ensino, deixam de lado uma tarefa fundamental da universidade: a pesquisa.

Desta forma, penso que uma estratégia fundamental para a universidade no próximo século será a prática da pesquisa. Isso envolve seu planejamento, sua necessária articulação com o ensino (processo de alimentação/retroalimentação), as estratégias para a busca de financiamento, cada vez mais escasso e num mercado cada vez mais competitivo. Esse será, a meu 
ver, o grande diferencial das universidades e o 'resguardo' das questões eminentemente acadêmicas. Um outro ponto estratégico fundamental, articulado com a pesquisa, parece-me ser a função social da universidade. Ela deve estar em diálogo constante com a comunidade, buscando pensar e equacionar seus problemas mais prementes. A pesquisa faz sentido na medida em que respondemos às necessidades sociais de nossa comunidade (seja ela a cidade, o país ou mesmo o mundo).

Certamente apenas esses dois pontos implicam em desdobramentos vários, e diversas possibilidades estratégicas; infelizmente, não me será possível tratálos nesse momento."

\section{Prof. Dr. Sílvio Gallo -Faculdade de Educação -} UNICAMP

\section{Depoimento $n^{\circ} 05$}

"1" Estratégia:

Deixar de ter o seu umbigo como referencial de planejamento e ação. Ou melhor: tomar como referência o mundo do trabalho contemporâneo, a vida social e cultural emergente... Mas para isso a Universidade precisa perder sua prepotência e arrogância com relação ao saber sobre as coisas do mundo da vida. Isto é, precisa estar predisposta e pré-ocupada em ouvir e conhecer melhor a vida do trabalho e das relações humanas: seus problemas e demandas... mais precisamente: precisa aprender a ouvir e conhecer de um modo diferente daquele que ainda predomina em seus departamentos...

2. Estratégia:

Envolver docentes/alunos/representantes dos diversos setores da sociedade para repensarem coletivamente/dialogicamente/reflexivamente a Universidade para o próximo século... estabelecendo, assim, uma ruptura com a tradição da racionalidade Técnica ou Instrumental da Universidade colonizar o mundo da vida (como denuncia Habermas).

É nesse processo de tentar dialogar e conhecer o mundo da vida com outros olhos e com novos aportes teóricos ou metodológicos que a Universidade irá, aos poucos, repensando sua função social, e daí, seu planejamento, suas mudanças (inclusive curriculares), suas ações que podem ser resumidos:

1) produção de novos conhecimentos a partir da prática, do mundo da vida, das relações humanas;
2) desenvolvimento de novos modos de produção de conhecimentos e de intervenção no mundo da vida (mais colaborativo, dialógico, participativo) onde prepondera a reflexão e as múltiplas perspectivas daqueles que vivem os desafios do mundo do trabalho, da vida social, da globalização e daqueles que tęorizam/pesquisam na universidade;

3) repensar a formação de novos profissionais na perspectiva de uma formação contínua ou do desenvolvimento profissional. Isto é, profissionais reflexivos, com capacidade de comunicar e de acessar, através da mídia (Internet, TV, computador,...), o conhecimento que vem sendo produzido no mundo, para, frente aos seus desafios, produzir seus próprios saberes práticos. Isso exigirá da universidade uma reestruturação curricular radical, invertendo a tendência atual de racionalidade Técnica que coloca as disciplinas teóricas no início e as práticas no final. Mas também não significa uma simples inversão. A mudança radical significa não separar, dicotomizar teoria e prática... Significa, na verdade, pensar e gestar teorias práticas ou práticas teorizadas."

Prof. Dr. Dario Fioorentini - Faculdade de Educação- UNICAMP

\section{Depoimento $n^{\circ} 06$}

"Ao meu ver, a Universidade deveria ser bastante cuidadosa com os apelos absolutos da globalização, sendo uma característica da contemporaneidade, que no futuro deverá encontrar um novo equilíbrio na revalorização do regional, do local e do cultural. Portanto, a Universidade futura será a sua poliformia e flexibilidade; assumindo uma forma bimodal, ou seja, será uma universidade de presença e à distância; assumir que o real não é absolutamente redutível ao conhecimento; deverá ser uma instituição com mais flexibilidade e mobilidade que a universidade atual; deverá assumir posição ante a ciência moderna predadora; não poderá mais continuar a defender um modelo de ciência falocêntrico; deverá buscar sempre novos equilíbrios entre o global e o local; deverá reequilibrar a matematicidade, a objetividade, a neutralidade que a moveram no seu esforço de domínio da natureza com a preocupação com a ecologia, a paz, a moral, o humano a serviço do que, afinal, a

Paidéia, FFCLRP-USP, Rib. Preto, jan/julho/2000. 
ciência e também o ensino devem estar. Nesse sentido deve ter uma visão da complexidade do real, isto é preciso que reintroduza o princípio da incerteza." Prof. Dr. Pedro Goergen Faculdade de EducaçãoUNICAMP

Depoimento $n^{0} 07$

"Pontos:

- ser local ao mesmo tempo que global;

- estrutura flexível e comprometida a participar cooperativamente na busca de solução para questões locais, regionais, nacionais e internacionais;

- ter como objetivo uma formação mais geral que profissional;

- ser menos voltado para o mercado e menos burocrático;

- deixar de ser 'uma federação' de escolas profissionais;

- deixar de considerar a cultura humanística como 'ornamental' e passar a considerá-la como fundamental e/ou eixo condutor de atividades profissionais;

- substituir o treinamento para um 'saber fazer' por uma postura de pesquisa intelectual - reflexão crítica em relação àquilo que se faz;

Estratégias:

- tempo de permanência na universidade mais estendido para que o aluno não frequiente só as aulas, mas também o ambiente cultural da universidade;

- redefinir a idéia de 'democratização do ensino';

- preparar para uma sociedade não mais em equilíbrio;

- não insistir numa transmissão e treinamento de habilidades mas no desenvolvimento do conhecimento;

- substituir a estrutura administrativa departamental;

- renovar aspectos institucionais."

Profa. Dra. Elisabete Monteiro de Aguiar PereiraFaculdade de Educação - UNICAMP

Paidéia, FFCLRP-USP, Rib. Preto, jan/julho/2000. 